\title{
AUSTRALIAN CARABID BEETLES XII. MORE TACHYS ${ }^{1}$
}

\author{
By P. J. Darlington, Jr.
}

Museum of Comparative Zoology, Cambridge, Mass.

This is, in effect, a continuation of Part XI (Darlington 1962) of my series of short papers on Australian Carabidae. The present part deals with some additional groups of Tachys.

\section{Tachys australis group}

This is a group of small, rather convex, usually rufous (sometimes blackish), shining species, with 5 or more punctate dorsal striae on each elytron. Previously known species of the group are those named in couplets 47 through 57 in Sloane's key (192I, 199) to Australian Tachys, plus Tachys yarrensis Blackburn, which (I think) Sloane placed incorrectly.

Technical characters of the australis group (partly derived from Sloane's key, I921, pp. 197-199) include upper surface not punctulate (except head in pubifrons); mentum 2-foveate at base; prothorax usually cordate, sometimes transverse (but if so, not notably wide across base); prothoracic angles without submarginal carinae; elytral margins behind humeri serrate and setulose (differently so in different species); 8th stria nearly entire or abbreviated anteriorly, formed anteriorly by a row of punctures, not bowed away from margin; elytron with 2 dorsal punctures; apical striole well developed, ending anteriorly about midway between suture and margin, with a strong puncture on its inner side behind middle of its length. Inner wings fully developed in most species but apparently dimorphic in semistriatus and reduced (or perhaps dimorphic) in olliffi; $0^{\lambda}$ with I seg. ment each front tarsus slightly dilated, slightly squamulose below; and $\sigma^{x}$ with $\mathrm{I}$, $q_{2}$ setae each side last ventral segment $\left(\sigma^{x} \sigma^{x}\right.$ examined of all species except yarrensis and olliffi, of which my specimens are all 우).

This group occurs throughout all or most of Australia including Tasmania, but is commonest in eastern and southeastern Australia. The members of the group live in damp or wet places, but I am not sure of the ecological limits of all the species. I have personally collected all of them except olliffi, but some of them were taken in flood debris so that I do not know their precise habitats. The group is not known to reach New Guinea (I have just completed what amounts

\footnotetext{
${ }^{1}$ This research was supported by National Science Foundation Grant NSF G 1393.

Manuscript received by the editor March 19, 1962.
} 
to a revision of New Guinean Tachys) and seems to have no close relatives there or in the Orient. Some Oriental species are superficially similar, but quite different in technical characters: e.g. Tachys ceylanicus (Niet.) has a superficial resemblance to australis etc. but has the mentum without foveae, differently formed 8th striae, and 2 segments of the $\sigma^{\pi}$ front tarsus widened and with squamules.

Although Sloane's key to the species of this group will separate them satisfactorily if used with care, he overlooked some striking and decisive characters that I shall use in the following key, which includes two new species.

Key to species of Tachys australis group

I. Elytra fully striate yarrensis

- Elytra not fully striate 2

2. Upper surface of head (but not rest of upper surface) extensively pubescent pubifrons

- Head not pubescent, except for usual fixed setae 3

3. Prothorax with extra marginal setae seticollis

- Prothorax with only usual 2 setae each side

4. Elytral margins fringed with long setae 4

- Elytral margins with normal, short setae

5. Prothorax with lateral margins obsolete

- Prothorax with lateral margins distinct punctipennis

6. Prothorax rather wide (W/L I.4O or more), sides not or scarcely sinuate posteriorly

bogani

- Prothorax narrower, with sides sinuate posteriorly semistriatus

7. Prothorax with sides long-sinuate (sinuation beginning well before base); color brown; very widely distributed in Australia

- Prothorax with sides short-sinuate; color usually blackish australis

8. Elytron 6-striate; wings fully developed; southwestern Australia habitans

- Elytron 5-striate; wings reduced; southeastern Australia .... olliff Tachys yarrensis Blackburn

Blackburn I 892, 20.

Sloane I $896,357,366$.

- I92 I, I99.

Blackburn described this Tachys from Upper Yarra (River), (east of Melbourne), Victoria. Sloane ( I896) records it from Mulwala, Urana, and Tamworth, New South Wales, "under logs and debris in very damp situations". I found 4 specimens in flood debris at Sale, southern Victoria, Oct. I, 1957. 
Blackburn and Sloane ( I92 I) thought that this species lacked an apical striole, but I think the striole is present but incorporated in the striation. The apex of the 3rd stria is deeply impressed for a short distance, arcuate, and with a puncture beside it on the inner side as in other species of the australis group, with which yarrensis agrees in most significant characters.

Tachys pubifrons $\mathrm{n}$. $\mathrm{sp}$.

With characters of australis group as given above. A rather slender member of group; reddish testaceous; shining, without (or nearly without) reticulate microsculpture above but head punctulate and setulose as described below. Head .77 \& .78 width prothorax; eyes moderate in size and prominence; antennae with segments $2 \& 3$ subequal, middle segments about $\mathrm{I} / 2 \times$ long as wide; whole front depressed from behind level of eyes to clypeal suture, the depression including the frontal foveae, which are not individually distinct, and which do not extend to clypeus; front also irregularly punctulate and pubescent; mentum conspicuously 2 -foveate at base. Prothorax cordate, width/length I.36 \& I.33; base/apex .99 \& .97; base/head .87 $\& .88$; sides rounded anteriorily, strongly converging posteriorly, sinuate well before angles and then subparallel to angles (the sinuations occur about I/ 7 of prothoracic length before angles); lateral margins poorly defined or partly obsolete; apex subtruncate with anterior angles rounded; base at most slightly and broadly lobed, slightly sinuate toward sides; basal angles sharply defined, approximately right; disc with anterior transverse impression and middle line vague, basal transverse sulcus moderately impressed, but interrupted at middle, coarsely punctate. Elytra with humeri rounded but prominent; margins behind humeri finely serrate and setulose; each elytron 6 -striate, with sutural stria entire, punctate anteriorly and groove-like posteriorly, and other striae formed of abbreviated rows of coarse punctures; stria 8 well impressed posteriorly, represented by a few punctures near middle, obsolete anteriorly; apical striole moderate, somewhat curved, ending about midway between suture and outer margin, with a coarse puncture on inner side well behind middle of its length; 3 rd interval with 2 fixed punctures slightly before $1 / 3$ and $2 / 3$ of elytral length. Inner wings fully developed. Secondary sexual characters as given for group. Measurements: length c. 2.5 or slightly more; width $c$. I.O mm.

Holotype $\sigma^{\pi}$ (M. C. Z. Type No. 30330) and 7 paratypes all from Termeil, southern New South Wales, October 1957, taken by myself. They were found under circumstances described under Tachys lutus (Darlington 1962, p. 1 20). 
The outstanding structural character of this species is the modification of the front of the head, which is unique, so far as I know. It is nearly uniform in all 8 specimens, which include both sexes.

Sloane $1896,358,366$.

\section{Tachys seticollis Sloane}

I92 I, I99.

The type locality is King's Sound, North West Australia. My 4 specimens are from widely separated localities: Bogan River (S. of Nyngan) in interior New South Wales, and near Cardwell and near Cairns in eastern tropical North Queensland. They were taken in wet places but not by freely running water.

\section{Tachys punctipennis (Macleay)}

Macleay I87I, in6 (Bembidium).

Sloane $1896,366$.

Sloane (I896) treats this as a synonym of monochrous ( = australis, v.i.), but I think he probably misidentified monochrous, which is probably an earlier name for findersi. I tentatively apply the name punctipennis to the present species (briefly characterized in the preceding key) because Macleay's superficial description seems to fit it and because it seems to be the commonest species of the group in South Queensland. I do not have it from the exact type locality, which is Gayndah, but I do have 28 specimens from other South Queensland localities including Brisbane and Jimna, and I have an additional series from the Richmond River near Wiangaree, northern New South Wales. I have also single specimens from 4 localities farther south in New South Wales, the 2 southernmost being Braidwood and Clyde Mt., I 30 or I 40 miles south of Sydney.

The outstanding recognition character of this species is the fringe of long setae on the elytral margins, combined with absence of extra setae on the prothoracic margins, but certain other characteristics of the species are noteworthy too. The lateral margins of the prothorax are partly obliterated in all specimens, being weak or obsolete behind the anterior marginal setae although more distinct in front of them. The inner wings are fairly long and more or less folded at tip, and in some individuals look fit for flight, but in other individuals the wings look so weak that I think they are probably flightless.

\section{Tachys semistriatus Blackburn}

Blackburn I888, $4 \mathrm{I}$.

Sloane 1896,358 .

- I920, I 5 I.

- I92I, 199 . 
Blackburn originally found this species in several places in swampy ground near Port Lincoln, South Australia. I collected it along the lower Murray River between Murray Bridge and Meningie, South Australia; in southern Victoria (between Portland and Port Fairy; near the lower Gellibrand River; and near Winchelsea); and in southern New South Wales (Bodalla, in flood debris). Sloane (I920) records it from several localities in Tasmania.

Blackburn described the species as piceous, the elytra with a large obscure reddish mark on disc a little behind middle. Most of my specimens answer this description, except that the ground color is dark reddish rather than piceous. In some specimens the elytra have
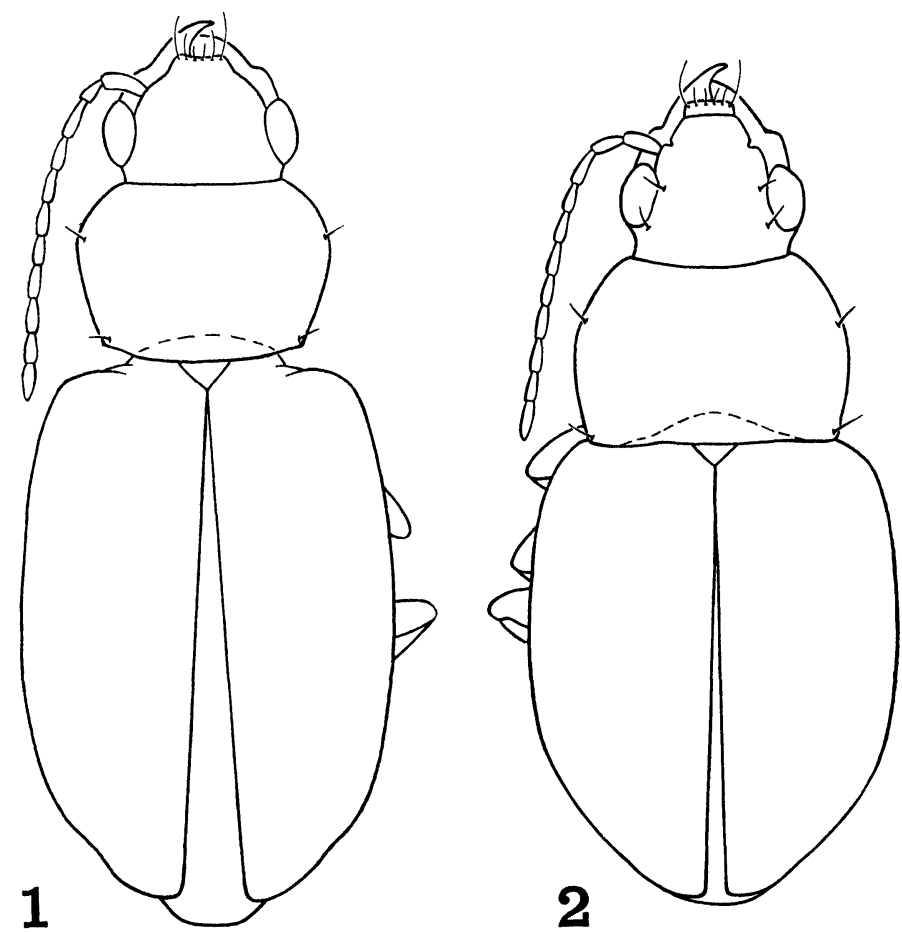

Figs. 1-2. Tachys. 1, T. bogani new species; 2, $T$. trunci new species.

an actual pale area as described. In others, careful examination shows that the elytra are almost uniformly colored but translucent, and in these specimens the paler areas are not spots on the elytra but the pale tips of the inner wings seen through the elytra. The wings of this 
species are apparently dimorphic. In most specimens the wings are slightly reduced, not folded or only slightly folded or crumpled at tip, and evidently unfit for flight. However my 4 specimens from between Murray Bridge and Meningie and I from Winchelsea possess large, complexly folded, probably usable inner wings.

\section{Tachys bogani n. sp.}

With characters of australis group as given above. Form as figured (Fig. I), slightly broader and more compact than usual in group; color reddish testaceous; shining, microsculpture absent above or nearly so. Head short, .79 \& .76 width prothorax; eyes moderately large and prominent; antennae with segments $2 \& 3$ subequal, middle segments about $2 \times$ long as wide; frontal foveae sublinear, converging anteriorly, extending onto clypeus, partly and vaguely duplicated anteriorly by slight grooves outside the main sulci; mentum conspicuously bifoveate at base. Prothorax broad; width/length I.4I \& I.4O; base/apex $c$. I.I9 \& I.2I; base/head I.03 \& I.03; sides rounded anteriorly, nearly straight and rather strongly converging posteriorly, then slightly and briefly sinuate before basal angles; apex truncate, anterior angles rounded; base broadly lobed, slightly sinuate and then oblique toward sides; posterior angles well defined but obtuse; disc with anterior transverse impression and middle line almost obsolete; basal transverse sulcus sharply impressed but interrupted at middle, not punctate. Elytra with humeri prominent but rounded; width elytra/ width prothorax I.44 \& I.38; margins behind humeri slightly serrate and setulose; elytron 6-striate, with sutural stria entire, punctate anteriorly and groove-like posteriorly, and other striae formed by abbreviated rows of rather coarse punctures; stria 8 well impressed posteriorly, obsolete anteriorly; apical striole rather short, slightly curved, not quite parallel to sutural stria, with a strong puncture on inner side behind middle of its length; 3rd interval with 2 dorsal punctures before $\mathrm{I} / 3$ and $2 / 3$ of elytral length. Inner wings fully developed. Secondary sexual characters as described for group. Measurements: length $c .2 .3$; width $c .0 .95 \mathrm{~mm}$.

Holotype $\sigma^{x}$ (M. C. Z. Type No. 3033I) and I o paratype both from Bogan River, south of Nyngan, New South Wales, October 1957, taken by myself probably by washing wet sand or debris beside pools in the bed of the Bogan River, which was not flowing at the time.

This species is distinguished from all others of the group by the virtually straight (scarcely sinuate) but converging sides of prothorax posteriorly. 
Schaum I 863, 90.

\section{Tachys australis Schaum}

monochrous Schaum I863, 90.

Sloane $1896,357,366$.

- I92 I, 199.

findersi Blackburn I888, 4I (new synonymy).

Sloane $1896,358,368$.

$$
1921,199 .
$$

tersatus Broun I893, I I IO (Bembidium) (new synonymy).

Schaum described this species under the heading Tachys australis, then on the same page erroneously used the name monochrous for it in the description. The two names are therefore absolute synonyms and the one used first, australis, should be recognized, as is done in the Junk-Schenkling Catalogue. Schaum's original specimen(s) were from Victoria, collected by Bakewell. I tentatively take as representing the species (but I do not mean to designate any kind of type or type locality) 3 specimens from Ferntree Gully, about 20 miles east of Melbourne, Victoria, collected Dec. 15, 1950, by W. L. Brown. Schaum's description calls for each elytron to have 6 dorsal striae formed by rows of punctures abbreviated apically. Revisers usually separate 6-striate and 5-striate individuals in this group of Tachys as different species, but the very short series from Ferntree Gully is by itself enough to show that this character is inconstant. Of the 3 Ferntree Gully individuals, one has the 6th stria represented by 4 punctures on the left elytron and 2 on the right; one, by one puncture on each side; and one, by no punctures on either side - that is, the last specimen is strictly 5-striate. Similar variation occurs in this species from some other localities. Failure of this character is one of the things that has persuaded me that findersi (supposedly 5-striate) is synonymous with australis (supposedly 6-striate). Additional indications are that Schaum's and Blackburn's descriptions seem to fit this species and that the species is common and widely distributed and therefore likely to fall into the hands of early collectors. "Bembidium" tersatum Broun, of which I have 2 (우) specimens from New Zealand received from $\mathrm{A}$. E. Brookes and answering the original description, agrees with the present species in general appearance as well as technical characters. The inner wings are large and folded in this species and look fit for flight.

Blackburn collected his specimens (types of findersi) near Port Lincoln and Adelaide, South Australia, on swampy ground and on the bank of the Torrens River. I have specimens from 22 localities, ranging from the middle part of the Cape York Peninsula (Iron 
Range and Coen) south to Victoria (Ferntree Gully) and Tasmania (Arve River) and west through South Australia (several localities). to Western Australia (Wiluna). Sloane ( 1896,368 ) records the species ("findersi") over an almost equally wide area including Central Australia. The presence of this species in New Zealand may be the result of introduction by man. It occurs under cover by standing or running water or in other wet places.

Sloane $1896,358,368$.

\section{Tachys habitans Sloane}

\section{I92 I, 199 .}

This is apparently a common species in southwestern Australia. Sloane's original specimens came from the Darling Ranges, Bridgetown, and Pinjarra. I took a series in the general vicinity of Perth and southward, at Mundaring Weir, Rottnest Island, Margaret River, Bridgetown, and Pemberton. My 33 specimens are all fully winged.

Sloane $1896,376$.

\section{Tachys olliffi Sloane} I92 I, 199.

This may be the southeastern representative of the southwestern habitans. Sloane described it from Forest Reefs (which he says elsewhere is in the district of Orange), New South Wales. I have one specimen from Vermont, at Dandenong Creek, east of Melbourne, Victoria, collected September 16, 195I, by W. L. Brown, and one from Mt. Lofty, South Australia, collected in October, 192I, by F. E. Wilson. Both these specimens have more or less reduced wings and are evidently flightless, but the species may turn out to be dimorphic.

\section{Tachys convexus and allied species}

Tachys convexus Macleay is a convex, 4-maculate, I-striate Tachys, with the basal sulcus of the pronotum 3 -foveate at middle. It is characterized also in Sloane's key (I92I) by stria 8 of elytron deeply impressed, with interval 9 convex; 2 fixed punctures on disc of elytron at position of third interval; apical striole present, with a fixed puncture on its inner side well back; prothorax with a transverse basal impression; humeri not specially modified; frontal sulci short; and (especially) posterior prothoracic angles reduced to small but prominent tubercles. Sloane ( I92I, 202-203), gives references and synonymy of the species. It is common and widely distributed especially in tropical Australia, living in damp, shady places by water. I have more than IOO specimens from eastern Queensland, from Cape York 
south to Brisbane, and it occurs also at Darwin and as far south as the Blue Mountains in New South Wales. It is not known to extend to New Guinea and has no close relatives there. Nevertheless an apparently distinct, related species occurs in a very small area near the tip of Cape York.

\section{Tachys convexulus $n$. sp.}

Form nearly as in convexus and with most characters of that species; convex, prothorax strongly narrowed behind and with dentiform subbasal posterior angles, and elytra broad and convex; color dark reddish, elytra 4-maculate (each with a posthumeral and subapical testaceous spot not very well defined), appendages testaceous; shining, without dorsal microsculpture or nearly so. Head .78 \& .77 width prothorax; eyes large and prominent; antennae rather short, segment 3 slightly longer than segment 2, middle segments less than $2 \times$ long as wide; frontal foveae short, not sharply defined; mentum not foveate at base, with simple tooth at middle. Prothorax roundedcordate; width/length I.2 I \& I.2O; strongly narrowed behind; base/ apex .96 \& 1.02 ; base/head $.86 \& .88$ (base measured across subbasal tubercles); sides strongly rounded anteriorly, nearly straight and strongly converging posteriorly but interrupted by small right or acute tubercles of subbasal angles; apex truncate with anterior angles rounded; base subtruncate; lateral margins narrow, each with usual 2 setae about I/3 from apex and on subbasal angles; disc very convex, with anterior transverse impression obsolete, middle line fine; transverse basal sulcus fine, without conspicuous foveae at middle, finely punculate. Elytra wide and convex (E/P I.39 \& r.40), widest not far behind humeri; humeri prominent but rounded; margins ending inwardly about middle of elytral width, slightly sinuate behind humeri but not serrate or setulose; sutural stria entire except light or abbreviated anteriorly, other dorsal striae lacking; stria 8 deep, entire, bowed away from margin at and before middle; apical striole as described for convexus; dorsal punctures before $\mathrm{I} / 4$ and not far behind $\mathrm{I} / 2$ of elytral length. Inner wings fully developed. Male tarsi not visibly modified; $\sigma^{\pi}$ with I, \& 2 setae apex last ventral segment. Length 2.I2.4 ; width $0.8-0.9 \mathrm{~mm}$.

Holotype $\sigma^{\star}$ (M. C. Z. Type No. 30334) and io paratypes all from Bamaga, near the northern tip of Cape York, January I958, taken by myself. They were, I think, washed from debris beside sluggish streams in shady places.

This species is smaller than convexus and slightly narrower but structurally similar except for the basal sulcus of the pronotum, 
which is conspicuously foveate in convexus, finely punctulate in convexulus. The two species are, I think, closely related but apparently distinct. The present new species seems to occur only in a very limited area, near but not quite on the tip of the Cape York Peninsula. It is within the range of convexus, which occurs at Lockerbie still farther north, almost on the actual tip of the Cape, but which I did not find at Bamaga. Only careful collecting, with detailed ecological notes, can show the relationships of these species to each other in nature. Two obvious possibilities are that convexulus may be a new species originating within the range of convexus, or that it may be an old species on the point of extinction.

\section{Tachys, group unknown}

\section{Tachys trunci $\mathrm{n}$. sp.}

Form as figured (Fig. 2), oval, convex, compact; dark reddish piceous, each elytron with a partial transverse-oblique pale fascia about $3 / 5$ from base, said fascia reaching neither margin nor suture, the inner end being further forward than the outer; appendages pale, maxillary palpi and outer part of antennae browner; very shining, without or almost without dorsal microsculpture (reticulations faintly indicated on front of head). Head .65 width prothorax; eyes moderate in size and prominence; antennae moderate, segments 2 and 3 subequal, middle segments less than $2 \times$ long as wide; frontal sulci linear, slightly diverging posteriorly, not crossing clypeus; mentum with two rather small foveae but not perforated, with median tooth. Prothorax transverse, strongly narrowed in front, slightly so behind; width/length I.53; base/apex I.43; base/head I.39; sides broadly arcuate through most of length, slightly but broadly sinuate before base; apex subtruncate with anterior angles narrowly rounded; base somewhat sinuously subtruncate; basal angles well defined, approximately right, strongly carinate, the carinae curving inward anteriorly; side margins narrow, a little wider posteriorly, each with usual 2 setae about $2 / 5$ from apex and near basal angle; disc very convex, anterior transverse impression linear, deeply impressed, entire (unusual in Tachys), middle line lightly impressed, not reaching base, basal transverse sulcus linear, faintly and finely punctulate, but interrupted and with a conspicuous fovea at middle. Elytra rather broadly oval; E/P I.28; lateral margins apparently ending at or just inside of humeri (this detail not clearly visible without manipulating the single specimen, which I am unwilling to do); margin behind humeri vaguely (hardly distinctly) subserrate and setulose; stria I (sutural) deeply impressed and entire, very deep and curving outward at base; other 
discal striae almost absent, inner ones very faintly indicated in good light, but abbreviated at both ends, stria 8 rather lightly impressed, parallel to margin, subinterrupted or punctate anteriorly; apical striole rather short, nearer margin than usual, but turning inward near anterior end, with a seta-bearing puncture on its inner side well back; two dorsal punctures on position of 3 rd interval near or slightly before I $/ 3$ and $2 / 3$ of elytral length. Inner wings probably fully developed but not examined. Lower surface essentially impunctate, not pubescent; prosternum impressed; mesosternal process not visible in the single specimen; tarsal claws slender, not serrate; $\sigma^{t}$ with front tarsi apparently unmodified, I seta each side last ventral segment. Length c. 2.3; width $\mathrm{I} .0 \mathrm{~mm}$.

Holotype $\sigma^{\pi}$ (M. C. Z. Type No. 30335) from west slope of Thornton Peak (Mt. Alexandra), near Daintree, North Queensland, December 1957, taken by my son (P. F. Darlington) on the trunk of a small tree in rain forest at probably about 3,000 ft. altitude. No other specimens were found.

This species is very different from any other known to me. In Sloane's key (I92I) it would probably run to couplet 43 , but it can hardly be related to any of the species there named (ectromioides, atridermis, etc.). Its arboreal habit suggests relationship to the nanus group of Tachys (which includes the Australian brunnipennis Macl.) and I have therefore compared it especially with the small, shining members of this group that occur in New Guinea (acuticollis Putz., wallacei Andr.), but the new species differs in having a shorter apical elytral striole, very different anterior pronotal impression, non-serrate claws, etc. It apparently does not fit in any Oriental group of the genus recognized by Andrewes ( 1925).

\section{References Cited}

ANDREwes, H. E.

1925. [Oriental Tachys.] Ann. Mus. Civ. Genoa, 51:327-502, 4 pls. BLACKBURN, T.

1888. [Australian Bembidiini.] Trans. R. Soc. South Australia, 10: $38-45$.

Broun, $T$.

1892. [Tachys yarrensis.] Trans. R. Soc. South Australia, 15: 20.

1893. Manual New Zealand Coleop., Part 5.

Darlington, P. J., JR.

1962. Australian carabid beetles XI. Some Tachys. Psyche, 69:117-128. MacleaY, W.

1871. ["Bembidium" from Gayndah.] Trans. Ent. Soc. New South SCHAUM, $\mathrm{H}$. Wales, 2: 115-120.

1863. [Tachys australis.] Berliner Ent. Zeitschrift, 7: 90. 
SLOANE, T. G.

1896. [Australian Tachys.] Proc. Linn. Soc. New South Wales, 21: 355-377, 407-409.

1920. Carabidae of Tasmania. Proc. Linn. Soc. New South Wales, 45:

113-178.

1921. [Australian Bembidiini.] Proc. Linn. Soc. New South Wales, 46: 192-208. 

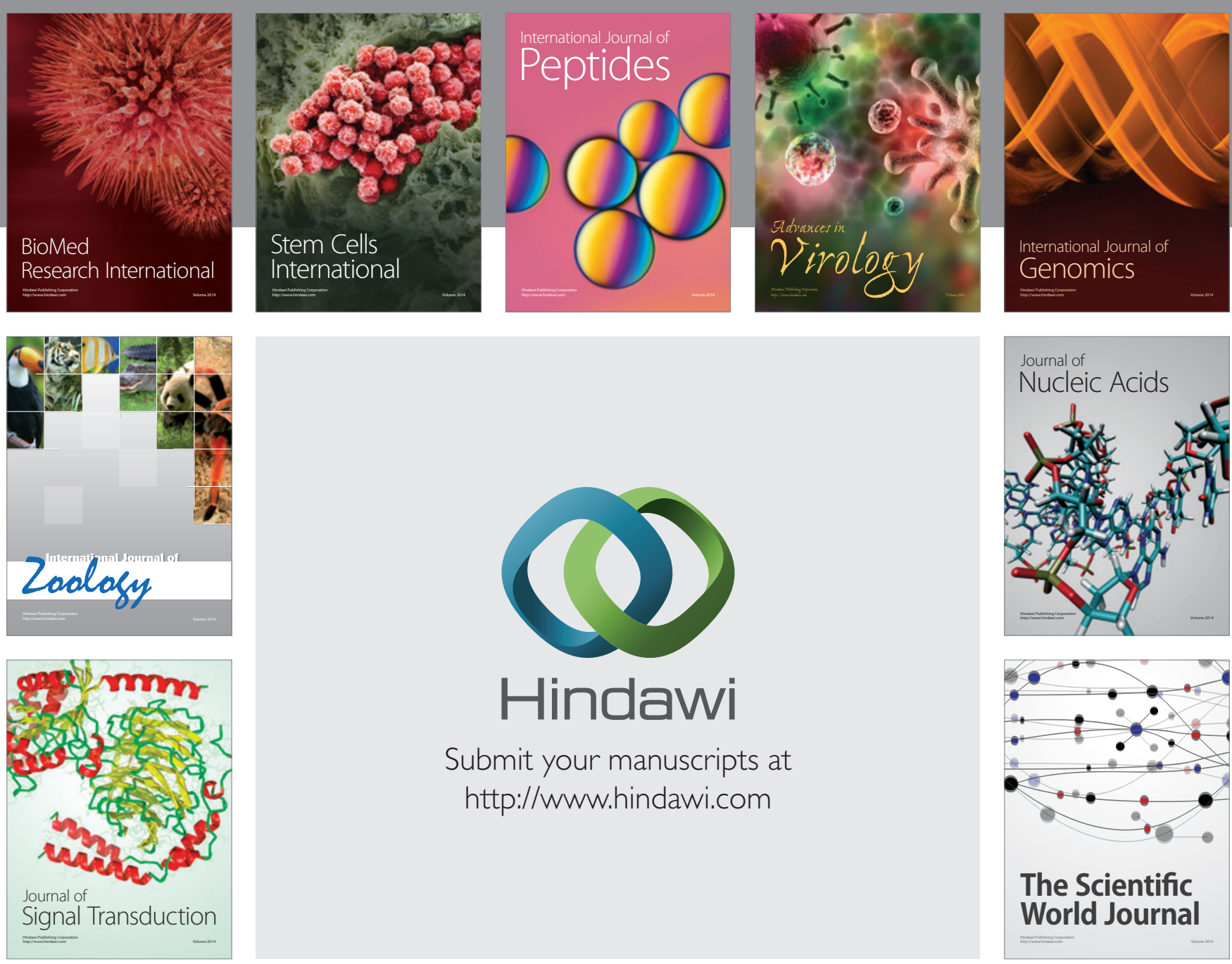

Submit your manuscripts at

http://www.hindawi.com
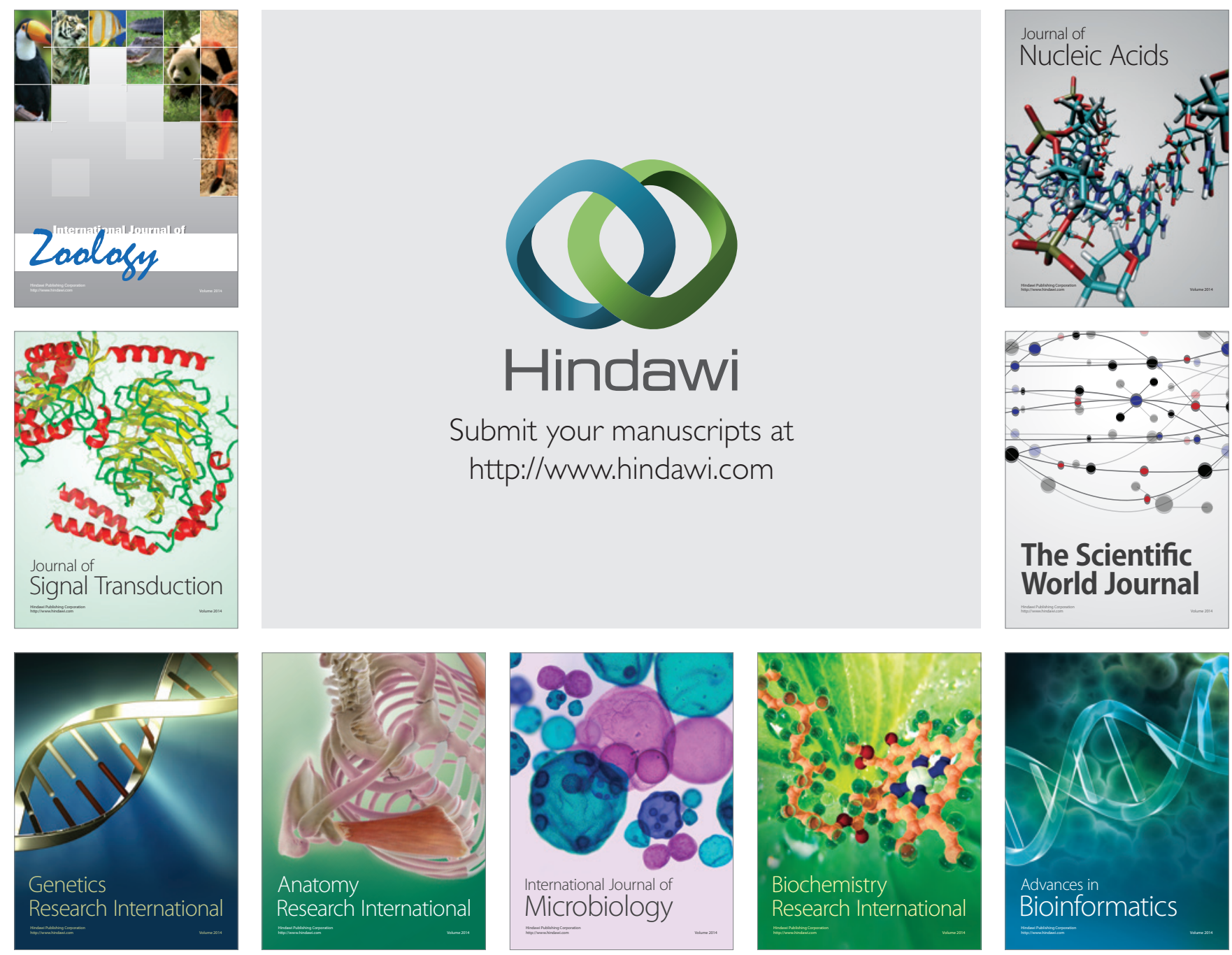

The Scientific World Journal
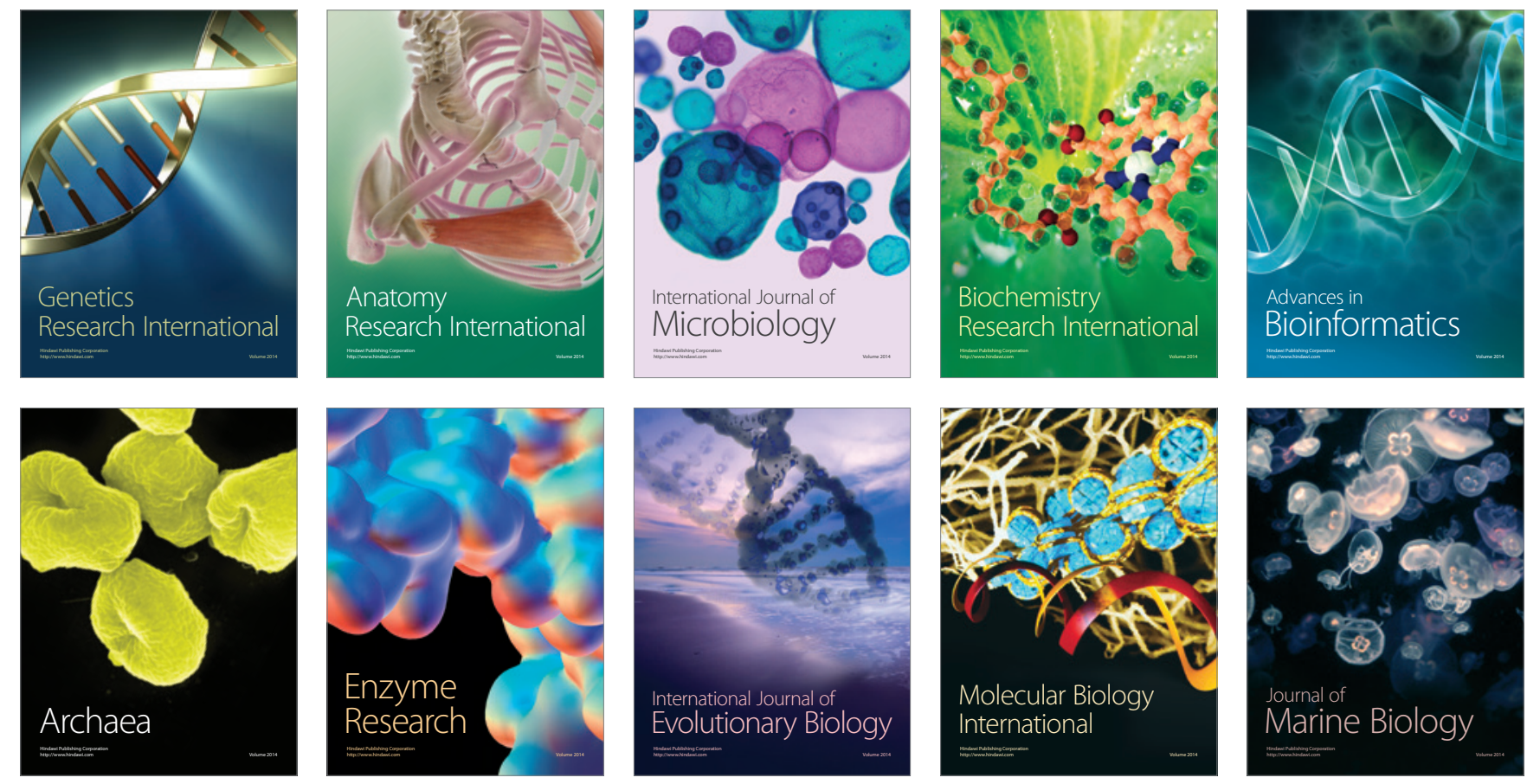